\title{
Editorial: the Conundrums of a Public Theology
}

One of the abiding concerns of a public theology is how do religious theme and practices enter into the pluralist public space. It is a conundrum which can take on several forms. Sometimes the biblical and theological reference point is hidden in history and scarcely even implicit in the present. Sometimes there is a strongly expressed theology but it is unable to secure the right to be heard in the public domain. The opposite can also be true: a strong activism without much of the way in an expressed theology can be persuasive. And then there is the role of the church as an institution. What is the role of the local congregation in the construction of a civil society? Is it possible for a public theology to be Christian if its advocate has no affiliation to the church and its confessional claims?

So often now the public Christian voice has become muted in contemporary western democracy. There is no absence of public issues upon which a faith-based activism can be played out. What is not always present is a strong supporting biblical or theological argument which can contribute to the public debate. For Mark Brett and Naomi Wolff the critical issue they seek to address in the Australian context is the matter of Indigenous sovereignty. It is one in which a number of diverse threads are woven into a knot all of which stem from the myth of the land being terra nullius and subsequently being subjected to invasion and colonization. The threads are discrete in and of themselves: they have to do with traditional law and custom, imperial and settler history, racism, politics and economics, dispossession and deprivation, and dignity and justice. It is no longer a foregone conclusion that the Christian faith has much to contribute, especially if and when, at certain points in that past history, it has been sadly complicit in acts of injustice.

Brett and Wolff demonstrate how Indigenous peoples are able to draw upon Scripture in an act of resistance and align it with customary knowledge. They probe beneath the surface of historic claims to sovereignty made in the interests of empire and demonstrate how biblical assumptions were able to justify invasive actions. Brett and Wolff contend that hidden away in this history and religious practice, nevertheless, is the potential for a model of sovereignty drawn from a biblical theology that supports the momentum for a long overdue treaty_in particular Deuteronomy 17:15. In contemporary Australia there 
has been an evident 'neglect of [these] biblical models'. Through its instruction not to set up a stranger as king over a people opens up the possibility of a more pluralist understanding of sovereignty. Brett and Wolff conclude that now it is a 'time for a new exchange of solemn promises' that cannot be 'washed away by the whim of new parliaments'.

One of the dilemmas that faces a public theology is that Christian praxis is not monolithic. The ideas, images, symbols and practices that lay claim to a Christian motivation for a theology of public life are contested and can be in overt competition. The plausibility of a Christian voice in the midst of multiple disciplines and other agencies at work in the public domain can become easily compromised. In footballing terms the effectiveness of a Christian public theology is always running the risk of becoming hamstrung through the scoring of an 'own goal'. It is a seldom addressed matter. Jeppe Nikolajsen does not address this concern directly, but the theme of his work to do with Christian ethics, public debate and pluralism for the sake of a stable and just community strongly resonates. Nikolajsen is alive to the highly pluralist nature of contemporary theological ethics and its 'societal situation' in a western democracy. Writing out of a Lutheran ethics Nikolajsen makes a helpful distinction between the need for a 'tradition-determined distinctiveness' and a 'traditiontranscending dialogue'. The debate is internal to the tradition. It can be seen as negotiating a way through the particular and universal aspects of a theological ethics. It can also be viewed in terms of the need to heed the advice of Nigel Biggar and manage a way between a 'theological thick position with a weak public engagement' and a 'thin position with a strong public engagement'. In due course Nikolajsen situates the theological premises of the tradition to which he belongs - its distinctiveness - into a dialogue that reaches out beyond itself into 'the midst of difference and diversity'. Its capacity to transcend allows for the accumulated ongoing wisdom of the tradition to be open and responsible to the society in which it now finds itself.

Sometimes the public issue that elicits a response lies within more selfconsciously within the orbit of the church's pastoral and moral concern. Theo Boer led a research team exploring the experience of pastors in the Protestant Church in the Netherlands with regards to legalized euthanasia. The public nature of this pastoral experience was a law passed in 2002 that allowed for the termination of life upon request and assisted suicide. It is a matter that prior to the passage of the law that had played itself out in the public domain. The act of committing euthanasia was thus decriminalized. With the passage of time the pastoral situation altered: initially the Euthanasia Act was deemed to be a 'doctor's act': it provided legal protection. Now it is seen more as a 
patient's right. The purpose of this research was to explore the response of a substantial number of pastors in order to discern their experience of handling requests alongside their theological, moral and spiritual views. In terms of a public theology the work is designed to record the professional integrity and public visibility of pastors on a matter that is of public concern. Boer et al. note the intersection of religion, public values and the private sphere. The pastoral responses to this 'explorative study' are conveyed through a set of statistical tables, hence emphasizing the need for an empirical practice that some internal critics of a public theology insist upon.

For Darren Cronshaw the pivotal concern has to do with how well does the local congregation in a particular denomination exhibit a public witness and relevance. The setting in which his statistical work takes place is the curious intersection identified in the United Kingdom of religious resurgence, institutional decline and secularism. Cronshaw is writing out of the Australian equivalent and doing so through the Baptist response to the National Church Life Survey (2016). Cronshaw is thus interested in the empirical evidence of how churches 'are embedded in the social fabric of local neighbours' and can be 'assets to the wider community'. In other words a local congregation can play a part in nurturing a civil society and do so through activities that may enhance the building up of those thin relationships. They can do so through the provision of social services, social actions and acts of advocacy. Back in 1995, in her Boyer Lectures on ABC Radio, Eva Cox identified how the well-being of a society depended upon the quality and extent of those thin relationships, especially at a time when the larger society is being shaped by forces that encourage greater competition amongst its citizens.

The final article by Jason Lam examines the location of the public theologian. What happens if, and when, the exponent of a public theology has little, if no, relationship to a professing community of faith? Is it sufficient to engage only with the academy and the public domain? Lam is effectively posing these questions against the background of an emerging Sino-Christian theology. It is a complex dialectic. The Christian faith has provided an intellectual life that opened up a reading of rights, justice, freedom and a pathway to modernity. At the same time it has been heavily implicated in the clash of cultural values and philosophies between the West and indigenous Chinese traditions and nationalism. The appeal of a Christian public theology has encouraged and inspired a number of public intellectuals whose primary setting is based in the university system in a cultural landscape that has become heterogeneous. One of the benefits of such is the capacity to use language less bound to dogmatic confessions. Lam wonders if engaging with public issues via Christian themes 
is 'really a kind of theology'. He notes that the churches have not possessed the time, energy and resources to develop such for themselves. Lam holds out the hope for a 'theologicity' where a Chinese theology is sensitive to public theology and its original religious vision.

Clive Pearson

Editor-in-Chief 